\title{
Cytotoxic and Genotoxic Effects of Zerumbone on WEHI 7.2 Wild Type Murine Thymoma Cells
}

\author{
Asmah Hamid ${ }^{1}$, Nor Fadilah Rajab ${ }^{1}$, Tay Shu Shen ${ }^{1} \&$ Mohd Nazir Nasrom $^{1}$ \\ ${ }^{1}$ Program of Biomedical Science, Faculty of Health Sciences, Universiti Kebangsaan Malaysia, Kuala Lumpur, \\ Malaysia \\ Correspondence: Asmah Hamid, Program of Biomedical Science, Faculty of Health Sciences, Universiti \\ Kebangsaan Malaysia, Jalan Raja Muda Abdul Aziz, Kuala Lumpur 50300, Malaysia. E-mail: \\ asmah0901@ukm.edu.my; asmah0901@yahoo.com
}

Received: October 3, 2017

Accepted: December 20, 2017

Online Published: December 31, 2017

doi:10.5539/jas.v9n13p1

URL: https://doi.org/10.5539/jas.v9n13p1

\begin{abstract}
Zerumbone (ZER), a sesquiterpene in the rhizomes of Zingiber zerumbet Smith, was shown to exhibit antiproliferative activities on various cancer cells. This study was carried out to determine the cytotoxic and genotoxic effects of ZER on WEHI 7.2 wild type murine thymoma cells through the employment of standard MTT assay, alkaline comet assay and flow cytometry Annexin V/PI. Results from the MTT assay demonstrated that ZER has a dose-dependent but not a time-dependent cytotoxic effect towards WEHI 7.2 wild type cells with $\mathrm{IC}_{50}$ values at 24,48 and 72 hours were $3.02 \pm 0.20 \mu \mathrm{g} / \mathrm{ml}(13.832 \mu \mathrm{M}), 2.73 \pm 0.13 \mu \mathrm{g} / \mathrm{ml}(12.503 \mu \mathrm{M})$ and $2.65 \pm 0.13 \mu \mathrm{g} / \mathrm{ml}(12.137 \mu \mathrm{M})$ respectively. Using $\mathrm{IC}_{10}$ and $\mathrm{IC}_{25}$ values obtained from the MTT assay, alkaline comet assay was carried out to detect DNA damage in ZER treated cells at three different time points $(1 / 2 \mathrm{~h}, 1 \mathrm{~h}$ and $2 \mathrm{~h}$ ). From the results, it was found that ZER induced significant DNA damage at all three time points for both concentrations $(p<0.05)$. Comparison of DNA damage levels at both concentrations suggested a concentration-dependent genotoxicity, as significantly higher values of tail DNA percentage and tail moment were obtained for cells treated with $\mathrm{IC}_{25}$ concentration $(\mathrm{p}<0.05)$. Furthermore, to understand the mode of cell death induced by ZER, flow cytometry Annexin V/PI was performed and it was found that cytotoxicity was achieved primarily via apoptosis. Collectively, ZER is able to induce genotoxicity in treated cells which subsequently leads to cytotoxicity via apoptosis and these presented characteristics suggest the compound as a potential anticancer drug.
\end{abstract}

Keywords: zerumbone, thymoma cell, apoptosis, genotoxicity, anticancer

\section{Introduction}

\subsection{Zerumbone}

Plant-based sophisticated traditional medicine systems had been built up since thousands of years ago and these plants continue to provide humans with new remedies (Ameenah, 2006). Compared to random screening, it is well agreed that potential novel structures are more likely to emerge from traditional medicine guided screening programs (Lee \& Houghton, 2005). According to an analysis of 155 clinically approved antitumor drugs worldwide between 1981 and 2006, 47\% of these drugs were non-modified natural products or derived from them (Newman \& Cragg, 2007). Zerumbone (ZER) is a monocyclic sesquiterpene present in large amount in the rhizomes of ginger plant, Zingiber zerumbet Smith (Oliveros \& Cantoria, 1982). This compound was found to possess a number of valuable medicinal properties. Native Malaysians, who commonly name this plant as 'lempoyang', widely made use of juice extracts from its fresh rhizomes to treat jaundice (Ong \& Norzalina, 1999). Apart from that, this plant is also used as stomach ache relief among Indonesians (Bhuiyan et al., 2009). Early studies revealed that ZER is able to suppress free radical generation and oxidative stress through induction of endogenous antioxidants, such as phase II xenobiotic metabolising enzymes, suppress proinflammation proteins and cancer cell proliferation. It is therefore suggested that this compound can be explored as cancer chemo preventive agent (Murakami et al., 1999, 2002, 2003; Nakamura et al., 2004). ZER was further found to exhibit antiproliferative effects on various actively dividing cell lines, including HL-60 human leukemic cells and NB4 promyelocytic leukemic cells via phase G2/M cell cycle arrest (Huang et al., 2005; Xian et al., 2007). Besides, ZER is also able to induce apoptosis in HepG2 human hepatocarcinoma cells, MCF-7 and CaCo-2 
breast cancer cells (Kirana et al., 2003; Sakinah et al., 2007). In this study, we demonstrated that ZER induces double-strand DNA breaks, which is an important event that triggers apoptosis, a preferable mode of cancer cell death.

\subsection{WEHI 7.2}

Murine tymoma cell WEHI 7.2 is a tymoma cells growing in BALB/C mice which induced through radiation. This cell was found unable to produce immunoglobin (Harris et al., 1973). WEHI 7.2 wild type on the other hands is a sub clone from selection of WEHI 7 at random (Danielsen et al., 1983; Harris et al., 1973). WEHI 7 is widely used in many apoptosis studies and provides a good culture model for immature thymocyte. This is because of the cell that contains a low base of bcl-2, thus experiencing apoptosis in response to various stimuli (Williams et al., 1998). In addition, the wild and infected type of WEHI 7.2 cells were also used in studies to identify the modes of action of molecule compounds in tumor cells (Efferth et al., 2005).

\section{Materials and Methods}

\subsection{Chemicals}

Pure zerumbone was obtained from Prof. Dr. Hasnah Mohd Sirat, Faculty of Science, Universiti Teknologi Malaysia (UTM). Doxorubicin hydrochloride, MTT salt, $\mathrm{NaCl}, \mathrm{Na}_{2} \mathrm{HPO}_{4}, \mathrm{KCl}, \mathrm{KH}_{2} \mathrm{PO}_{4}, \mathrm{PBS} \mathrm{Mg}^{2+}$ and $\mathrm{Ca}^{2+}$ free tablet, EDTA, Tris, Triton X-100, NaOH, normal melting agarose (NMA), low melting agarose (LMA), ethidium bromide, propidium iodide and Giemsa stain were purchased from Sigma, USA. Fluorescein isothiocyanate-labelled Annexin V (Annexin V-FITC) and 10X binding buffer were obtained from BD Pharmingen, USA, while Trypsin/EDTA $0.25 \%$ was purchased from Lonza, USA. DMSO was obtained from Fisher Scientific, UK.

\subsection{Cells and Cell Culture}

WEHI 7.2 wild type murine thymoma cells (15) is a gift from Prof. Gwyn T. William, University of Keele, UK, while Chang liver cells (16) were obtained from American Type Culture Collection (ATCC). Both cell lines were cultured in RPMI-1640 medium supplemented with $10 \%$ fetal bovine serum. Cells were maintained at $37{ }^{\circ} \mathrm{C}$ in $5 \% \mathrm{CO}_{2}$ atmosphere. Further subculturing and maintenance of cells were done every 2-3 days using standard cell culture procedure.

\subsection{MTT Cytotoxicity Assay}

For WEHI 7.2 wild type cells, serial dilution of ZER and doxorubicin from $60 \mu \mathrm{g} / \mathrm{ml}$ to $0 \mu \mathrm{g} / \mathrm{ml}$ was done in 96-well microplate. Cells were then seeded at $1 \times 10^{6}$ cells $/ \mathrm{ml}$ concentration. Final concentration of treatment compound and cell suspension were $0-30 \mu \mathrm{g} / \mathrm{ml}$ and $5 \times 10^{5}$ cells $/ \mathrm{ml}$ respectively. Chang liver cells were seeded in 96-well microplate at $5 \times 10^{4}$ cells $/ \mathrm{ml}$ and then incubated at $37{ }^{\circ} \mathrm{C}$ in $5 \% \mathrm{CO}_{2}$. After 24 hours, the medium was removed and replaced with fresh medium containing test compounds at concentration ranging from 0-30 $\mu \mathrm{g} / \mathrm{ml}$. Two triplicate cultures were established for each treatment for both cell lines. Microplates were then incubated at $37{ }^{\circ} \mathrm{C}$ in $5 \% \mathrm{CO}_{2}$ for treatment time $(24 \mathrm{~h}, 48 \mathrm{~h}$ and $72 \mathrm{~h})$. After treatment period, $20 \mu \mathrm{l}$ MT in PBS solution (5 $\mathrm{mg} / \mathrm{ml}$ ) was added to all wells and the plates were further incubated for 4 hours. Supernatant were then removed and $150 \mu \mathrm{l}$ DMSO was added to all wells to dissolve formazan crystals. Plates were incubated for 15 minutes to ensure all crystals were dissolved before absorbance of each well at $570 \mathrm{~nm}$ was measured using ELISA plate reader. Data obtained were converted to inhibition percentage curves. $\mathrm{IC}_{50}$ values represent compound concentration needed to reduce viability cells percentage to $50 \%$ of those in the untreated control wells.

\subsection{Flow Cytometry Annexin V/PI}

WEHI 7.2 wild type cells were seeded in 6-well plate at $5 \times 10^{5}$ cells $/ \mathrm{ml}$ and treated with ZER and doxorubicin at $\mathrm{IC}_{50}$ concentration obtained from 24 hour MTT curve. Plate was then incubated at $37{ }^{\circ} \mathrm{C}$ in $5 \% \mathrm{CO}_{2}$ for 24 hours. After that, suspension from each well was transferred to tube and centrifuged at $2500 \mathrm{rpm}, 4{ }^{\circ} \mathrm{C}$, for $5 \mathrm{~min}$. The supernatant was removed and pellet was washed with $\mathrm{Ca}^{2+}$ and $\mathrm{Mg}^{2+}$ free PBS and recentrifuged. Following the removal of supernatant, pellet was suspended in $150 \mu \mathrm{l}$ binding buffer. $2.5 \mu \mathrm{l}$ Annexin V FITC was added and tubes were left in the dark for 15 minutes. After that, $10 \mu l$ propidium iodide (PI) was added and tubes were left in the dark again for 3 minutes. Suspension were then transferred into Falcon tubes embedded in ice and were analysed by using BD FACSCanto II Flow Cytometer.

\subsection{Alkaline Comet Assay}

WEHI 7.2 wild type cells, seeded in 6 -well plate at $5 \times 10^{5}$ cells $/ \mathrm{ml}$, were treated with test compounds at $\mathrm{IC}_{10}$ and $\mathrm{IC}_{25}$ for $1 / 2 \mathrm{~h}, 1 \mathrm{~h}$ and $2 \mathrm{~h}$. Following incubation, suspension was transferred to tube for centrifugation (2500 $\mathrm{rpm} / 5 \mathrm{~min}$ at $4{ }^{\circ} \mathrm{C}$ ). The supernatant was then removed and pellet was washed with $\mathrm{Ca}^{2+}$ and $\mathrm{Mg}^{2+}$ free $\mathrm{PBS}$ and 
recentrifuged. After the removal of supernatant, the pellet was mixed thoroughly with $80 \mu 1$ of $0.6 \%$ LMA (w/v). The mixture was pipette onto slides layered with hardened $0.6 \%$ NMA (w/v) and cover slips were placed to spread the mixture. Slides were then left on ice for LMA to solidify. Subsequently, cover slips were removed and slides were immersed in a lysing buffer containing $2.5 \mathrm{M} \mathrm{NaCl}, 100 \mathrm{mM} \mathrm{Na}{ }_{2}$ EDTA, $10 \mathrm{mM}$ Tris and 1\% Triton $\mathrm{X}-100$ for $1 \mathrm{~h}$ at $4{ }^{\circ} \mathrm{C}$ to lyse the embedded cells. Slides were then soaked in electrophoresis buffer solution for 20 min to unwind DNA before electrophoresis was run at $300 \mathrm{~mA}, 25 \mathrm{~V}$ for $20 \mathrm{~min}$. After that, the slides were rinsed thrice with neutralizing buffer for $5 \mathrm{~min}$ each time and stained with $45 \mu \mathrm{l}$ ethidium bromide solution. All slides were left overnight in $4{ }^{\circ} \mathrm{C}$ before being observed under fluorescence microscope equipped with $590 \mathrm{~nm}$ filter (Leica, Germany) and camera. Comet slides analysis was done by using CometScore ${ }^{\mathrm{TM}}$ software (TriTek Corp, USA) and parameters recorded were $\%$ DNA in tail and tail moment.

\subsection{Statistical Analysis}

Statistical analysis was performed by using Statistical Package for the Social Sciences (SPSS) version 19. Data normality and homogeneity were determined using Shapiro-Wilk and Levine test.One way analysis of variance (ANOVA) and post-hoc Tukey test were used to compare between groups. All data were presented as the mean \pm standard error of mean (S.E.M.). A $p$ value of $<0.05$ was considered statistically significant.

\section{Results}

\subsection{Cytotoxic Effects of Zerumbone}

The cytotoxic effects of ZER on WEHI 7.2 wild type thymoma cell were studied by performing MTT assay. Viability of WEHI 7.2 wild type cells against ZER concentration after $24 \mathrm{~h}, 48 \mathrm{~h}$ and $72 \mathrm{~h}$ treatment are shown in Figure 1. At highest ZER concentration, which is $30 \mu \mathrm{g} / \mathrm{ml}(137.400 \mu \mathrm{M})$, average viability of treatment cells decreased from $100 \%$ viability in vehicle control to $5.17 \pm 0.37 \%$ after $24 \mathrm{~h}, 3.58 \pm 0.35 \%$ after $48 \mathrm{~h}$ and $4.12 \pm 0.34 \%$ after $72 \mathrm{~h}$. Significant decrease in viable cells after $24 \mathrm{~h}$ and $48 \mathrm{~h}$ treatment occurred at ZER concentrations as low as $0.9375 \mu \mathrm{g} / \mathrm{ml}(4.294 \mu \mathrm{M})$ till $30 \mu \mathrm{g} / \mathrm{ml}(p<0.05 \mathrm{vs}$. control), while for $72 \mathrm{~h}$ treatment, significant decrease in viable cells occurred at higher ZER concentration, which is $1.875 \mu \mathrm{g} / \mathrm{ml}(8.588 \mu \mathrm{M})$ till $30 \mu \mathrm{g} / \mathrm{ml}\left(p<0.05\right.$ vs. control). From the graph, $\mathrm{IC}_{50}$ value of ZER treated cells for $24 \mathrm{~h}, 48 \mathrm{~h}$ and $72 \mathrm{~h}$ were $3.02 \pm 0.20 \mu \mathrm{g} / \mathrm{ml}(13.832 \mu \mathrm{M}), 2.73 \pm 0.13 \mu \mathrm{g} / \mathrm{ml}(12.503 \mu \mathrm{M})$ and $2.65 \pm 0.13 \mu \mathrm{g} / \mathrm{ml}(12.137 \mu \mathrm{M})$ respectively. 

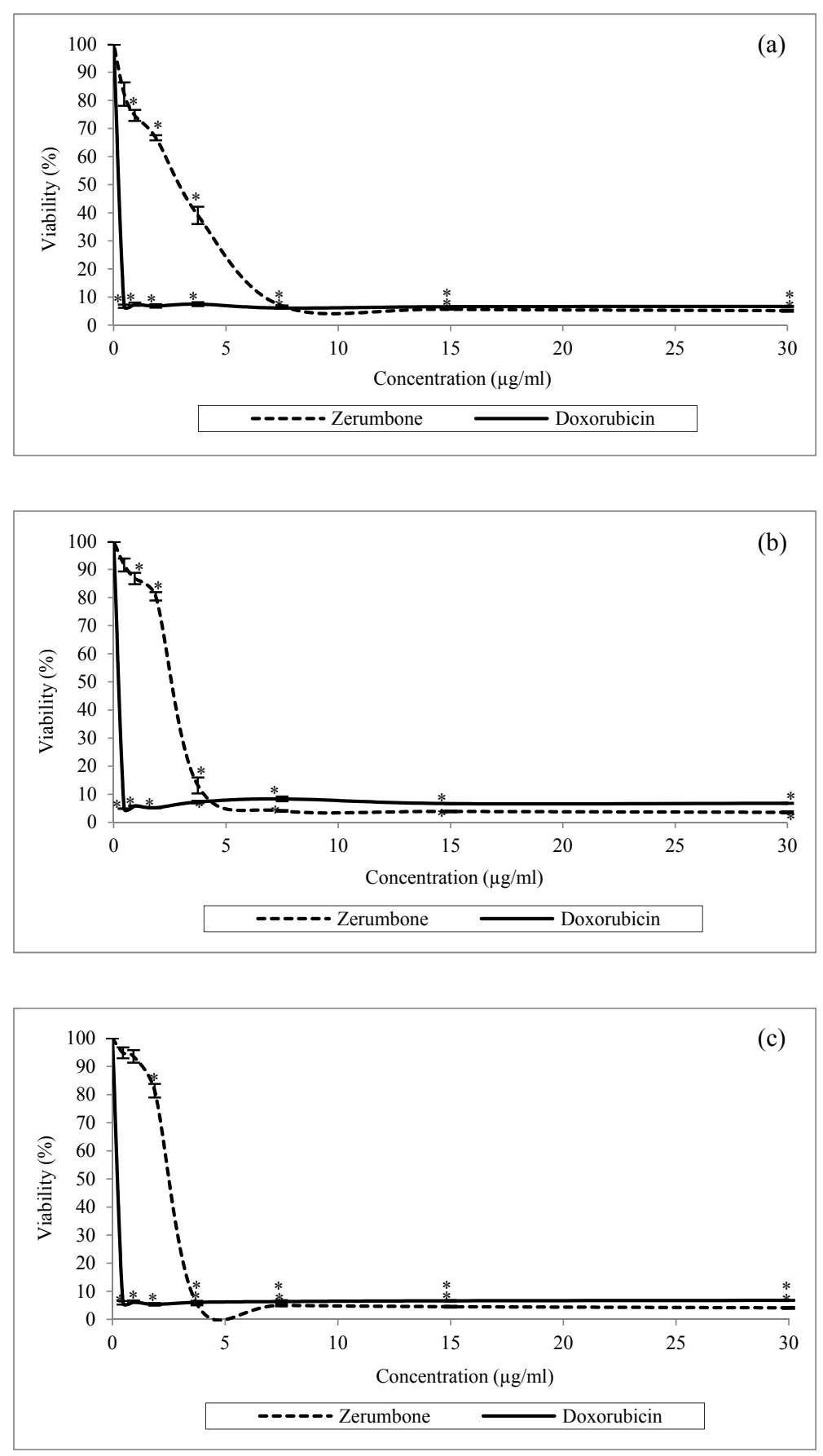

Figure 1. Cytotoxic effect of zerumbone on WEHI 7.2 wild type cells after (a) $24 \mathrm{~h}$, (b) $48 \mathrm{~h}$ and (c) $72 \mathrm{~h}$ treatment

Note. The results are the mean \pm S.E.M. of two triplicates in three separate experiments; ${ }^{*} p<0.05$ vs. control.

MTT assay was also carried out on Chang liver cells to examine cytotoxic effects of zerumbone on non-transformed cell line. Viability of Chang liver cells against ZER concentration after $24 \mathrm{~h}, 48 \mathrm{~h}$ and $72 \mathrm{~h}$ treatment are shown in Figure 2. Based on the experiment, cell viability decreased from $100 \%$ viability in vehicle control to $30.72 \pm 4.67 \%$ after $24 \mathrm{~h}, 20.83 \pm 0.76 \%$ after $48 \mathrm{~h}$ and $27.81 \pm 4.85 \%$ after $72 \mathrm{~h}$ at highest ZER concentration of $30 \mu \mathrm{g} / \mathrm{ml}(137.400 \mu \mathrm{M})$. Significant decrease in viable cells after $24 \mathrm{~h}$ and $72 \mathrm{~h}$ treatment occurred at ZER concentrations as high as $7.5 \mu \mathrm{g} / \mathrm{ml}(34.350 \mu \mathrm{M})$ till $30 \mu \mathrm{g} / \mathrm{ml}(p<0.05 \mathrm{vs}$. control), while for $48 \mathrm{~h}$ treatment, significant decrease in viable cells occurred only at a higher ZER concentration of $15 \mu \mathrm{g} / \mathrm{ml}$ 
$(68.700 \mu \mathrm{M})$ till $30 \mu \mathrm{g} / \mathrm{ml}\left(p<0.05\right.$ vs. control). IC $_{50}$ value of ZER treated Chang liver cells for $24 \mathrm{~h}, 48 \mathrm{~h}$ and $72 \mathrm{~h}$ were $18.82 \pm 0.87 \mu \mathrm{g} / \mathrm{ml}(86.196 \mu \mathrm{M}), 15.69 \pm 0.26 \mu \mathrm{g} / \mathrm{ml}(71.860 \mu \mathrm{M})$ and $27.81 \pm 4.86 \mu \mathrm{g} / \mathrm{ml}(127.370 \mu \mathrm{M})$ respectively.
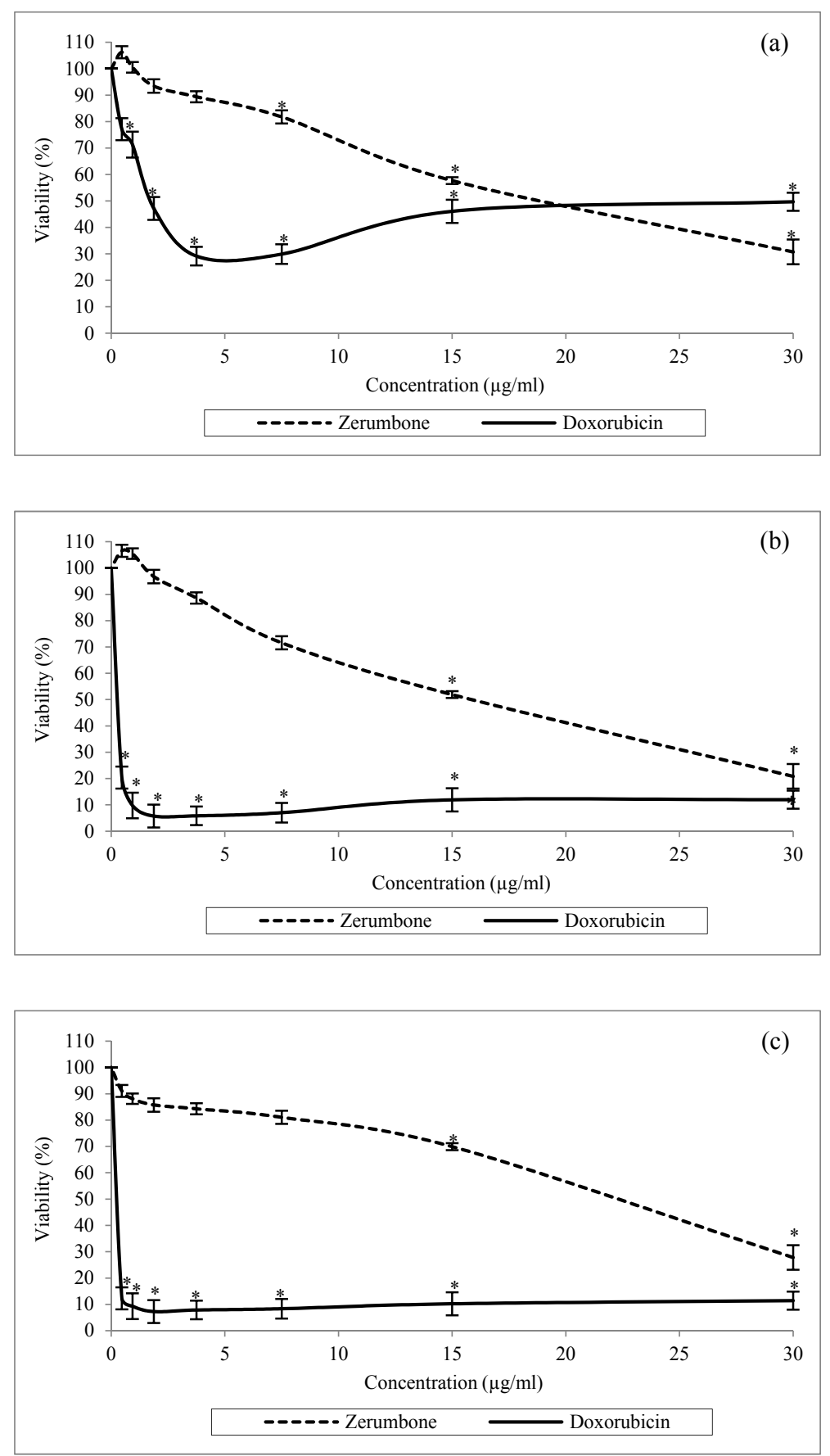

Figure 2. Cytotoxic effect of zerumbone on Chang liver cells after (a) $24 \mathrm{~h}$, (b) $48 \mathrm{~h}$ and (c) $72 \mathrm{~h}$ treatment Note. The results are the mean \pm S.E.M. of two triplicates in three separate experiments; ${ }^{*} p<0.05$ vs. control.

To evaluate the selectivity and common toxicity of zerumbone, selectivity index was calculated by using calculation method as described by Badisa et al. (2009).

$$
\text { Selectivity Index }(\mathrm{SI})=\frac{\mathrm{IC}_{50} \text { value of non transformed cells }}{\mathrm{IC}_{50} \text { value of malignant cells }}
$$


Table 1. Cytotoxic effect of zerumbone on WEHI 7.2 wild type thymoma cells and non-transformed Chang liver cells

\begin{tabular}{llll}
\hline & $24 \mathrm{~h}$ & $48 \mathrm{~h}$ & $72 \mathrm{~h}$ \\
\hline $\mathrm{IC}_{50}(\mu \mathrm{g} / \mathrm{ml} \pm \mathrm{SEM})$ & & & \\
Chang liver & $18.82 \pm 0.87(86.196 \mu \mathrm{M})$ & $15.69 \pm 0.26(71.860 \mu \mathrm{M})$ & $27.81 \pm 4.86(127.370 \mu \mathrm{M})$ \\
WEHI 7.2 wild type & $3.02 \pm 0.20(13.832 \mu \mathrm{M})$ & $2.73 \pm 0.13(12.503 \mu \mathrm{M})$ & $2.65 \pm 0.13(12.137 \mu \mathrm{M})$ \\
Selectivity Index (SI) & 6.23 & 5.75 & 10.49 \\
\hline
\end{tabular}

\subsection{Flow Cytometry Annexin V/PI}

Flow Cytometry Annexin V/PI was employed to investigate the mode of cell death induced by ZER. ZER treated WEHI 7.2 wild type cells at $\mathrm{IC}_{50}$ concentration were found to exhibit a higher percentage of apoptotic cells compared to necrotic cells (Table 2). At $24 \mathrm{~h}$ treatment, the percentage of apoptotic and necrotic cells were $26.53 \pm 1.62 \%$ and $4.65 \pm 1.02 \%$ respectively. Besides, the percentage of late apoptotic cells was also found to be higher than early apoptotic cells (Figure 3). Meanwhile, percentage of necrotic cells were only $4.65 \pm 1.02 \%$ and not significant from control $(p>0.05)$.

Table 2. Comparison of percentage of apoptotic and necrotic cells in $24 \mathrm{~h}$ treated WEHI 7.2 wild type cells

\begin{tabular}{lll}
\hline & Apoptosis & Necrosis \\
\hline Control & $7.00 \pm 0.97 \%$ & $2.55 \pm 0.54 \%$ \\
$\mathrm{IC}_{50}$ Zerumbone & $26.53 \pm 1.62 \% *$ & $4.65 \pm 1.02 \%$ \\
$\mathrm{IC}_{50}$ Doxorubicin & $36.87 \pm 3.87 \% *$ & $3.38 \pm 0.83 \%$ \\
\hline
\end{tabular}

Note. The results are the mean \pm S.E.M. of three separate experiments; $* p<0.05$ vs. control.

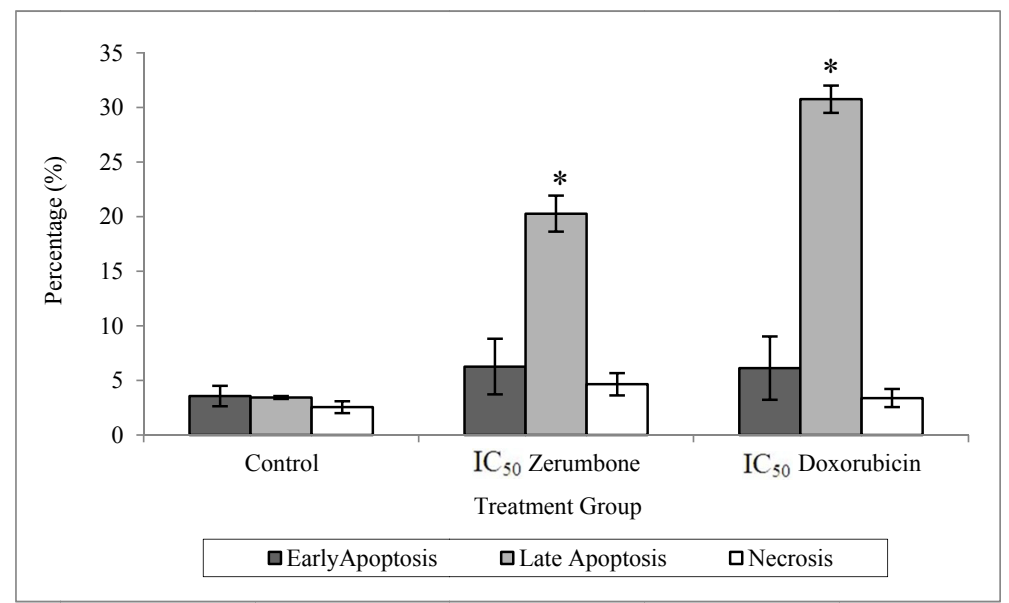

Figure 3. Mode of cell death following treatment of WEHI 7.2 wild type cells for $24 \mathrm{~h}$

Note. The results are the mean \pm S.E.M. of three separate experiments; ${ }^{*} p<0.05$ vs. control. 

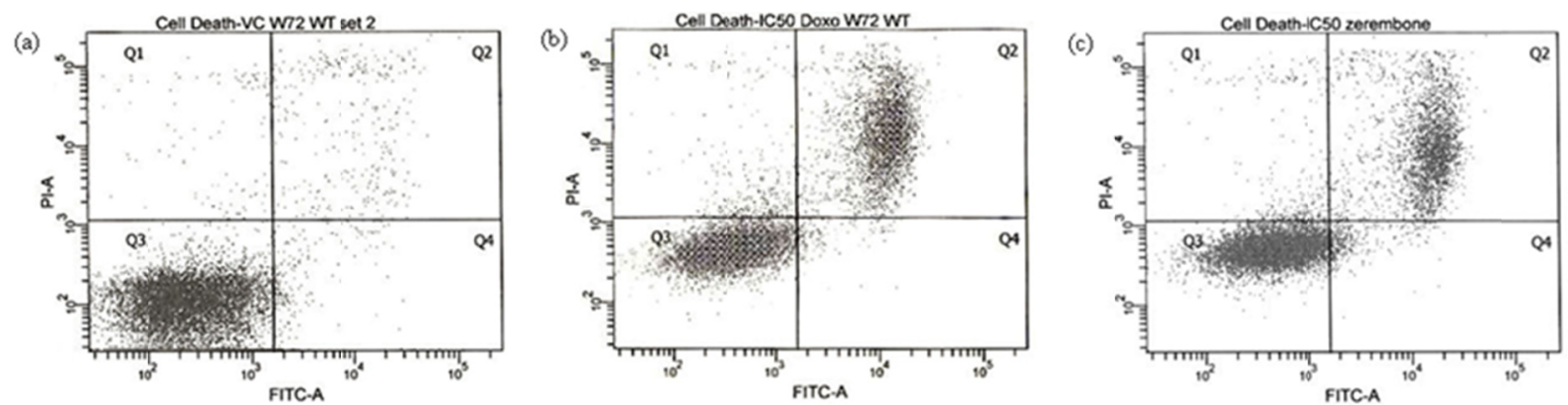

\begin{tabular}{|ll|}
\hline Q1: Necrosis & Q3: Viable \\
Q2: Late Apoptosis & Q4: Early Apoptosis \\
\hline
\end{tabular}

Figure 4. Representative contour diagrams out of duplicates from three separate experiments for treated WEHI 7.2 wild type cells. (a) to (c) represents control group, zerumbone treated group at $\mathrm{IC}_{50}$ dose and doxorubicin treated group at $\mathrm{IC}_{50}$ dose respectively

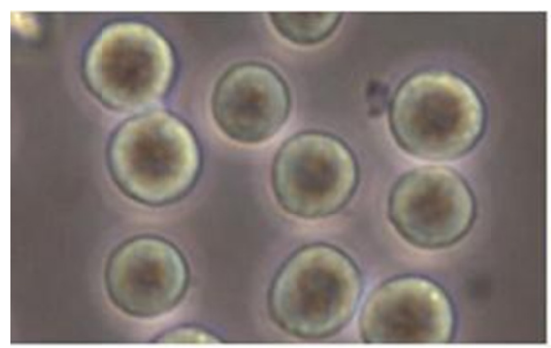

(a) Control

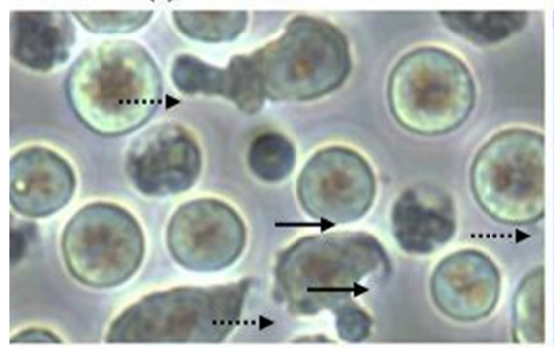

(b) $\mathrm{IC}_{50}$ Zerumbone

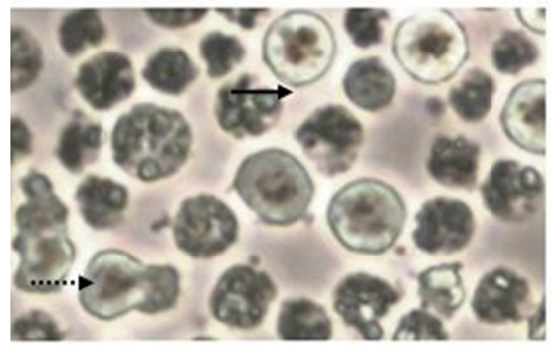

(c) $\mathrm{IC}_{50}$ Doxorubicin

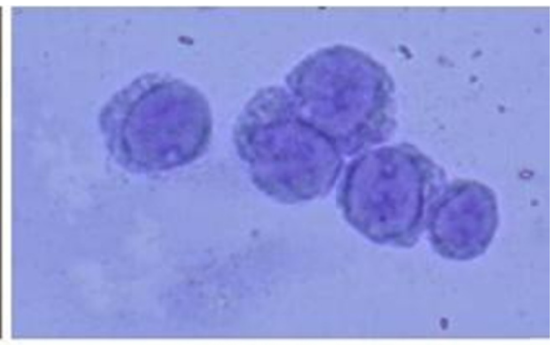

(d) Control

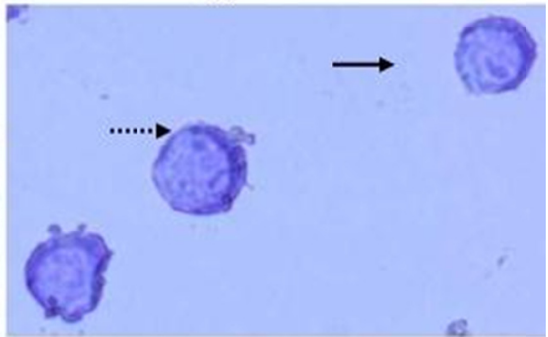

(e) $\mathrm{IC}_{50}$ Zerumbone

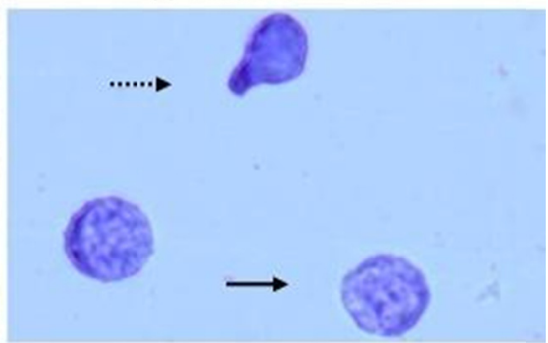

(f) $\mathrm{IC}_{50}$ Doxorubicin

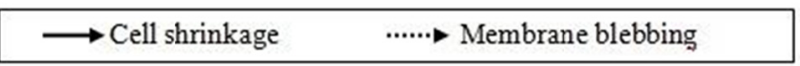

Figure 5. Apoptotic features observed in zerumbone treated WEHI 7.2 wild type cells under light microscope. (a) to (c) show unstained cells while (d) to (f) are cells stained with Giemsa

\subsection{Genotoxic Effects of Zerumbone}

Any DNA damage in WEHI 7.2 wild type cells induced by ZER was detected by using comet alkaline assay and results are represented by Figure 6. ZER treated cells were found to show significant DNA damage as early as $1 / 2 \mathrm{~h}$ at both treatment concentration $(p<0.001)$. Half hour treatment at $\mathrm{IC}_{50}$ concentration removed $8.29 \pm 0.61 \%$ DNA from the nucleus while a higher $15.81 \pm 0.74 \%$ DNA were removed from nucleus at $\mathrm{IC}_{25}$ concentration. Tail 
moment value at $\mathrm{IC}_{10}$ and $\mathrm{IC}_{25}$ concentration were 6.05 \pm 0.57 A.U. and 13.10 \pm 1.25 A.U. respectively. The degree of DNA damage was found to increase following increment of ZER concentration and also treatment time. Tail DNA \% and tail moment values for $1 \mathrm{~h}$ and $2 \mathrm{~h}$ treatment were significantly higher compared to $1 / 2$ treatment were significant at both concentration $(p<0.001)$. Besides, difference between tail DNA\% for $1 \mathrm{~h}$ and $2 \mathrm{~h}$ treatment at $\mathrm{IC}_{25}$ concentration was also found to be significant $(p<0.05)$. More than $90 \%$ cell DNA in control group was found to remain intact.\% DNA in tail of control group is as low as $0.91 \pm 0.10 \%$ for $\mathrm{IC}_{10}$ treated group and $1.42 \pm 0.19 \%$ for $\mathrm{IC}_{25}$ treated group, while tail moment value were $0.05 \pm 0.01$ A.U. and $0.07 \pm 0.03$ A.U. respectively.
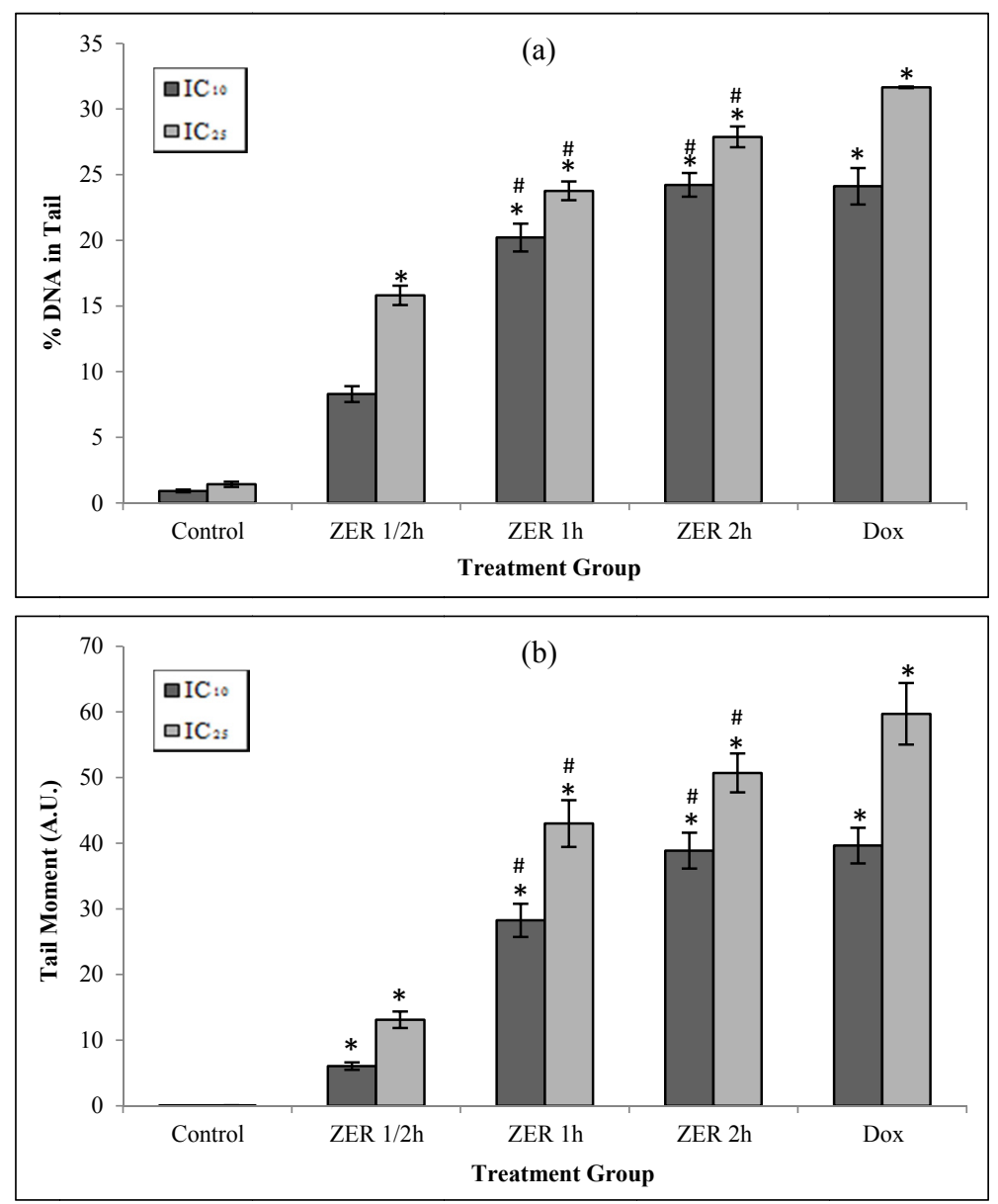

Figure 6. Degree of DNA damage expressed as (a) \% DNA in tail and (b) tail moment (A.U.) following 1/2 h, 1 $\mathrm{h}$ and $2 \mathrm{~h}$ treatment at $\mathrm{IC}_{10}$ and $\mathrm{IC}_{25}$ concentration. ZER $\mathrm{IC}_{10}$ and $\mathrm{IC}_{25}$ were 1.37 and $2.03 \mathrm{~g} / \mathrm{ml}$, respectively

Note. The results are the mean \pm S.E.M. of three separate experiments; ${ }^{*} p<0.05$ vs. control; \# $p<0.05$ vs. ZER $1 / 2 \mathrm{~h}$. 


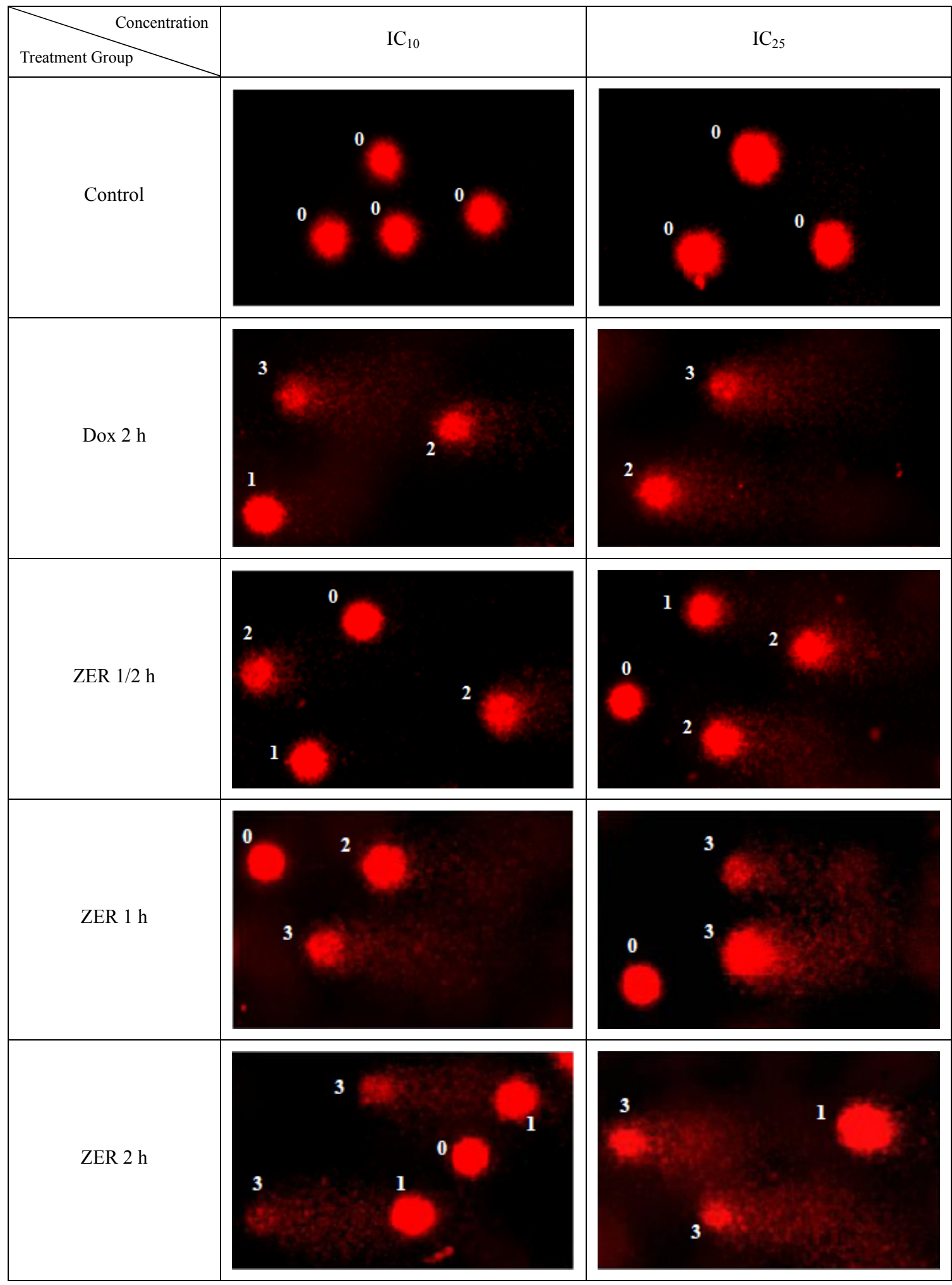

Figure 7. Treated WEHI 7.2 wild type cells exhibited different DNA damage score following different treatment time and concentration. Score 0: undamaged cells; score 1, 2, 3: less to more damaged cells

\section{Discussion}

Zerumbone, extracted from the rhizomes of ginger plant Zingiber zerumbet Smith, was found to exhibit anti-proliferative activities on various malignant cell lines, including HL-60 human leukemic cells and NB4 
promyelocytic leukemic cells, induce apoptosis in HepG2 human hepatocarcinoma cells and is also a potential chemopreventive agent (Murakami et al., 1999; Huang et al., 2005; Sakinah et al., 2007). Our study focused on assessing the cytotoxic and genotoxic effect of zerumbone. Based on reduction of tetrazolium salt to quantifiable purple formazan crystal, viability of treated WEHI 7.2 wild type cells and Chang liver cells were determined by MTT assay (Mosman, 1983).

In plants screening program carried out by the National Cancer Institute (NCI, USA), a compound is generally regarded as having in vitro cytotoxic activity if its $\mathrm{IC}_{50}$ value in malignant cells is less than $20 \mu \mathrm{g} / \mathrm{ml}$ for crude extracts and less than $4 \mu \mathrm{g} / \mathrm{ml}$ for pure compound (Lee \& Houghton, 2005). Our current data shows that $\mathrm{IC}_{50}$ value for pure zerumbone treated WEHI 7.2 wild type cells at all three time points were less than $4 \mu \mathrm{g} / \mathrm{ml}$ and therefore exhibit in vitro cytotoxic activity. This result is in agreement with previous studies where zerumbone was found to show cytotoxic and anti-proliferative activities towards actively dividing cell lines, including leukemia, hepatocarcinoma and colon carcinoma (Murakami et al., 2002; Xian et al., 2007; Sakinah et al., 2007). Besides, data obtained also suggested that the activity of zerumbone is dose-dependent but not time-dependent, as the viability of cells decreased with increased zerumbone concentration but there are no significant differences between the $\mathrm{IC}_{50}$ values for all three time points.

To evaluate the common cytotoxicity and selectivity of zerumbone, cytotoxicity assay was also carried out on non-malignant Chang liver cells. ZER was found to exhibit weak cytotoxic effect on Chang liver cells with $\mathrm{IC}_{50}$ at all three time points were in the range of $18-28 \mu \mathrm{g} / \mathrm{ml}$. According to Badisa et al. (2009), selectivity index reflects the ability of a compound to exert its effect selectively; that is the higher the value of selectivity index, the higher the ability of a compound to kill cells selectively. Badisa et al. (2009) also pointed out that a lower than 2 selectivity index value indicates the common toxicity of a compound. Therefore, from our results, we may conclude that ZER is a highly selective compound and is less effective on non-malignant Chang liver cells.

Induction of WEHI 7.2 wild type cell death by ZER may be via apoptosis or necrosis. Many antitumor therapies exert their effect through activation of apoptosis (Fesik, 2005). This mode of death is preferable as phagocytic cells are able to recognize and remove apoptotic bodies without causing inflammation around dead cells (Edinger \& Thompson, 2004). Our result demonstrated that ZER induce cell death via apoptosis and therefore has the potential to be developed as anticancer agent. This result is in agreement with previous findings of Xian et al. (2007) and Sakinah et al. (2007), which was done on NB4 leukaemia cells and HepG2 hepatocarcinoma cells. However, it was noted that there was discrepancy between $\mathrm{IC}_{50}$ value determined by MTT assay and percentage of dead cells evaluated by flow cytometry Annexin V/PI. Although cells were treated at $\mathrm{IC}_{50}$ concentration obtained from MTT assay graph, percentage of dead cells recorded by using flow cytometry is less than $40 \%$. As addressed by McKim et al. (2005), this phenomenon may occur due to involvement of two different end-points in assessment. Cytotoxicity measured by different methods may give $\mathrm{IC}_{50}$ values which vary widely compare to standard MTT assay. While measurement of cell viability by using MTT assay is based on reduction of MTT salt by viable cells, detection of dead cells in flow cytometry Annexin V/PI depends on integrity of cell plasma membranes (Mosmann, 1983; Vermes et al., 1995).

Alkaline comet assay, which allows detection of individual cell DNA damage, was performed as there is possibility that cytotoxicity of ZER is caused by ZER induced DNA damage (Singh et al., 1988). Genotoxic evaluation was done at two concentrations, namely $\mathrm{IC}_{10}$ and $\mathrm{IC}_{25}$, to prevent false positive resulted from DNA strand breaks caused by cell death (Handerson et al., 1998). In addition, parameters were picked based on following reasons. Despite giving the most stable prediction for DNA damage, using tail moment (tail length X DNA in tail) as sole parameter may mask induction effects in certain cases. An increase in tail length and decrease in DNA in tail result in a stable tail moment (Boeck et al., 2000). Therefore, DNA in tail was addressed in addition to tail moment as it was found to be consistent throughout electrophoresis sessions and experiments (Lee et al., 2004).

In this study, results showed that $\%$ DNA in tail and tail moment values increased significantly with treatment time and concentration. This indicates that longer treatment period and higher ZER concentration will cause greater DNA damage in ZER treated WEHI 7.2 wild type cells. Genotoxicity of ZER is confirmed by meeting two criteria stated below. Firstly, there is a greater level of DNA damage following employment of higher concentration of ZER; and secondly, DNA damage is significantly different from negative control in at least two treatment concentrations (both $\mathrm{IC}_{10}$ and $\mathrm{IC}_{25}$ ) (Dean \& Danford, 1984; Scott et al., 1990).

Although alkaline comet assay detects single and double DNA strand breaks, single strand breaks are not the main players. These breaks can be quickly repaired and therefore is not regarded as mutagenic lesion or impairment which can cause significant death (Collins et al., 1997). However, some studies showed that for the 
possibility of DNA repair and rejoin to occur, DNA damage level must be lower than 25\% DNA in tail (Chan et al., 2006). From our results, it is observed that except for $2 \mathrm{hr}$ treatment at $\mathrm{IC}_{25}$ concentration, all other treatment groups presented lesser than $25 \%$ DNA in tail. This explained our situation where $75 \%$ observed nuclei appeared as comets though cells were treated at only $\mathrm{IC}_{10}$ and $\mathrm{IC}_{25}$ concentration.

Gathering results presented in this study, we concluded that ZER is able to induce genotoxicity in treated malignant cells which subsequently leads to selective cytotoxicity via apoptosis and these presented characteristics suggest the compound as a potential anticancer drug.

\section{Conclusion}

Zerumbone shows a potent cytotoxic effect on the WEHI 7.2 wild type murine thymoma cells. The cytotoxic properties shown are selectively. In addition, this compound is also shown to cause genotoxicity on the cell. Zerumbone induced thymoma cell apoptosis. Combining the specified characteristics, zerumbone will be able to induce genotoxicity in the treatment that causes cytotoxicity through apoptosis in the cell. Thus this compound found to have the potential to be developed as anticancer agents.

\section{Acknowledgements}

This work was financially funded by Ministry of Education Fundamental Research Grant Scheme (UKM-NN-07-FRGS0152-2010) and by School of Diagnostic and Applied Sciences, Faculty of Health Sciences, UKM.

\section{References}

Ameenah G. F. (2006). Medicinal plants. Traditions of yesterday and drugs of tomorrow. Molecular Aspects of Medicine, 27, 1-93. https://doi.org/10.1016/j.mam.2005.07.008

Badisa, R. B., Darling-Reed, S. F., Joseph, P., Cooperwood, J. S., Latinwo, L. M., \& Goodman, C. B. (2009). Selective cytotoxic activities of two novel synthetic drugs on human breast carcinoma MCF-7 cells. Anticancer Research, 29, 2993-2996.

Bhuiyan, M. N. I., Chowdhury, J. U., \& Begum, J. (2009). Chemical investigation of the leaf and rhizome essential oils of Zingiber zerumbet (L.) Smith from Bangladesh. Bangladesh Journal of Pharmacology, 4, 9-12. https://doi.org/10.3329/bjp.v4i1.845

Chan, K. M., Rajab, N. F., Ishak, M. H. A., Ali, A. M., Yusoff, K., Din, L. B., \& Inayat-Hussain, S. H. (2006). Goniothalamin induces apoptosis in vascular smooth muscle cells. Chemico-Biological Interactions, 159, 129-140. https://doi.org/10.1016/j.cbi.2005.10.107

Chang, R. S. (1954). Continuous subcultivation of epithelial-like cells from normal human tissues. Proceedings of the Society for Experimental Biology and Medicine, 87, 440-443. https://doi.org/10.3181/0037972787-21406

Collins, A. R., Dobson, V. L., Dušinská, M., Kennedy, G., \& Štětina, R. (1997). The comet assay: What can it really tell us? Mutation Research, 375, 183-193. https://doi.org/10.1016/S0027-5107(97)00013-4

Danielsen, M., Peterson, D. O., \& Stallcup, M. R. (1983). Immunological selection of variant mouse lymphoid cells with altered glucocorticoid responsiveness. Molecular and Cellular Biology, 3(7), 1310-1316. https://doi.org/10.1128/MCB.3.7.1310

De Boeck, M., Touil, N., De Visscher, G., Vande, P. A., \& Kirsh-Volders, M. (2000). Validation and implementation of an internal standard in comet assay analysis. Mutation Research, 469, 181-197. https://doi.org/10.1016/S1383-5718(00)00075-9

Dean, B. J., \& Danford, N. (1984). Assays for the detection of chemically-induced chromosome damage in cultured mammalian cells. In S. Venitt \& J. M. Parry (Eds.), Mutagenicity Testing: A Practical Approach (pp. 187-232). England: IRL Press Limited, Oxford. https://doi.org/10.1016/S0142-9612(03)00132-7

Edinger, A. L., \& Thompson, C. B. (2004). Death by design: apoptosis, necrosis and autophagy. Current Opinion in Cell Biology, 16, 663-669. https://doi.org/10.1016/j.ceb.2004.09.011

Efferth, T., Rauh, R., Kahl, S., Tomicic, M., Bochzelt, H., Tome, M. E., ... Kaina, B. (2005). Molecular modes of action of cantharidin in tumor cells. Biochemical Pharmacology, 69, 811-818. https://doi.org/10.1016/ j.bcp.2004.12.003

Fesik, S. W. (2005). Promoting apoptosis as a strategy for cancer drug discovery. Nature Reviews Cancer, 5(11), 876-885. https://doi.org/10.1028/nrc1736 
Harris, A. W., Bankhurst, A. D., Mason, S., \& Warner, N. L. (1973). Differentiated functions expressed by cultured mouse lymphoma cells. II. Theta antigen, surface immunoglobulin and a receptor for antibody on cells of a thymoma cell line. J. Immunology, 110(2), 432-438.

Henderson, L., Wolfreys, A., Fedyk, J., Bourner, C., \& Windebank, S. (1998). The ability of the comet assay discriminate between genotoxins and cytotoxins. Mutagenesis, 13(1), 89-94. https://oi.org/10.1093/ mutage/13.1.89

Huang, G. C., Chien, T. Y., Chen, L. G., \& Wang, C. C. (2005). Antitumor effects of Zerumbone from Zingiber

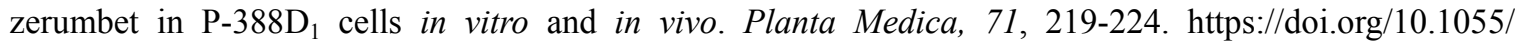
s-2005-837820

Kirana, C., Mclntosh, G. H., Record, I. R., \& Jones, G. P. (2003). Antitumor activity of extract of Zingiber aromaticum and its bioactive sesquiterpenoid zerumbone. Nutrition and Cancer, 45(2), 218-225. https://doi.org/10.1207/S15327914NC4502_12

Lee, C. C., \& Houghton, P. (2005). Cytotoxicity of plants from Malaysia and Thailand used traditionally to treat cancer. Journal of Ethnopharmacology, 100(3), 237-243. https://doi.org/10.1016/j.jep.2005.01.064

Lee, E., Oh, E., Lee, J., Sul, D., \& Lee, J. (2004). Use of the tail moment of the lymphocytes to evaluate DNA damage in human biomonitoring studies. Toxicology Sciences, 81, 121-132. https://oi.org/10.1093/ toxsci/kfh 184

McKim Jr., J. M. Wilga, P. C., Pregenzer, J. F., \& Petrella, D. K. (2005). A biochemical approach to in vitro toxicity testing. Pharmaceutical Discovery, January, 30-36. https://doi.org/10.1016/j.ceb.2004.09.011

Mosmann, T. (1983). Rapid colorimetric assay for cellular growth and survival: Application to proliferation and cytotoxicity assays. Journal of Immunological Methods, 65(1-2), 55-63. https://doi.org/10.1016/0022-1759 (83)90303-4

Murakami, A., Hayashi, R., Takana, T., Ki, H. K., Ohigashi, H., \& Ratu, S. (2003). Suppression of dextran sodium sulfate-induced colitis in mice by zerumbone, a subtropical ginger sesquiterpene, and nimesulide: separately and in combination. Biochemical Pharmacology, 66, 1253-1261. https://doi.org/10.1016/ S0006-2952(03)00446-5

Murakami, A., Takahashi, D., Kinoshita, T., Koshimizu, K., Ha, W. K., Yoshihiro, A., ... Ohigashi, H. (2002). Zerumbone, a Southeast Asian ginger sesquiterpene, markedly suppresses free radical generation, proinflammatory protein produciton, and cancer cell proliferation accompanied by apoptosis: The $\alpha \beta$-unsaturated carbonyl group is a prerequisite. Carcinogenesis, 23(5), 795-802. https://doi.org/10.1093/ carcin/23.5.795

Murakami, A., Takahasi, M., Jiwajinda, S., Koshimizu, K., \& Ohigashi, H. (1999). Identification of zerumbone in Zingiber zerumbet Smith as a potent inhibitor of 12-O-Tetradecanoylphorbol-13-acetate-induced Epstein-Barr virus Activation. Bioscience, Biotechnology, and Biochemistry, 63(10), 1811-1812. https://doi.org/10.1271/bbb.63.1811

Nakamura, Y., Yoshida, C., Murakami, A., Ohigashi, H., Osawa, T., \& Uchida, K. (2004). Zerumbone, a tropical ginger sesquiterpene, activates phase II drug metabolizing enzymes. FEBS Letters, 572, $245-250$. https://doi.org/10.1016/j.febslet.2004.07.042

Newman, D. J., \& Cragg, G. M. (2007). Natural products as sources of new drugs over the last 25 years. Journal of Natural Products, 70(3), 461-477. https://doi.org/10.1021/np068054v

Oliveros, M.B. \& Cantoria, M.C. (1982). Pharmacognostic studies on Zingiber zerumbet (Linné) Smith and its proposed variety (Family Zingiberaceae). International Journal of Crude Drug Research, 20(3), 141-153. https://doi.org/10.3109/13880208209055190

Ong, H. C., \& Norzalina, J. (1999). Malay herbal medicine in Gemencheh, Negri Sembilan, Malaysia. Fitoterapia, 70, 10-14. https://doi.org/10.1016/S0367-326X(98)00023-9

Sakinah, S. A. S, Handayani, S. T., \& Hawariah, L. P. A. (2007). Zerumbone induced apoptosis in liver cancer cells via modulations of Bax/Bcl-2 ratio. Cancer Cell International, 7, 1-11. https://doi.org/10.1186/ 1475-2867-7-4

Scott, D., Dean, B. J., Danford, N. D., \& Kirkland, D. J. (1990). Metaphase chromosome aberration assays in vitro. In D. J. Kirkland (Ed.), Basic Mutagenicity Tests: UKEMS Recommended Procedures (pp. 62-86). Cambridge: UKEMS/University of Cambridge Press. 
Singh, N. P., McCoy, M. T., Tice, R. R., \& Schneider, E. L. (1988). A simple technique for quantitation of low levels of DNA damage in individual cells. Experimental Cell Research, 175, 184-191. https://doi.org/ 10.1016/0014-4827(88)90265-0

Vermes, I., Haanen, C., Steffens-Nakken, H., \& Reutelingsperger, C. (1995). A novel assay for apoptosis. Flow cytometric detection of phosphatidylserine expression on early apoptotic cells using fluorescein labelled Annexin V. Journal of Immunological Methods, 184, 39-51.https://doi.org/10.1016/0022-1759(95)00072-I

Williams, G. T., Critchlow, M. R., Hedge, V. L., \& O’Hare, K. B. (1998). Molecular failure of apoptosis: Inappropriate cell survival and mutagenesis? Toxicology Letters, 102-103, 485-489. https://doi.org/10.1016/S0378-4274(98)00343-9

Xian, M., Ito, K., Nakazato, T., Shimizu, T., Chen, C., Yamato, K., ... Kizaki, M. (2007). Zerumbone, a bioactive sesquiterpene, induces $\mathrm{G} 2 / \mathrm{M}$ cell cycle arrest and apoptosis in leukemia cells via a Fas- and mitochondria-mediated pathway. Cancer Science, 98(1), 118-126. https://doi.org/10.1111/j.1349-7006 2006.00362.x

\section{Copyrights}

Copyright for this article is retained by the author(s), with first publication rights granted to the journal.

This is an open-access article distributed under the terms and conditions of the Creative Commons Attribution license (http://creativecommons.org/licenses/by/4.0/). 